\title{
BRAF V600 Mutation Profile of Metastatic Melanoma in the Thrace Region of Turkey
}

\author{
Nuray CAN' ${ }^{1}$ Ebru TAŞTEKIN', Tülin DENIZ YALTA', Necdet SÜT², Selma KORKMAZ , Ufuk USTA',

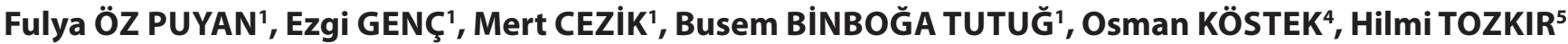

Department of 'Pathology, ${ }^{2}$ Biostatistics, Trakya University, Faculty of Medicine, Balkan Campus, EDIRNE, TURKEY

${ }^{3}$ Department of Dermatology, Suleyman Demirel University, Faculty of Medicine, ISPARTA, TURKEY

Department of ${ }^{4}$ Internal Medicine, Division of Medical Oncology, ${ }^{5}$ Medical Genetics, Trakya University, Faculty of Medicine, Balkan Campus, EDiRNE, TURKEY

\section{ABSTRACT}

Objective: BRAF is the most common mutation in melanoma. The most common subtype is BRAF V600E, followed by V600K. Initially, the authors aimed to investigate whether clinicopathological features of melanoma are associated with BRAF mutations. We then aimed to present the relationships between the clinicopathological features and the mutated subtype (V600E vs V600K).

Material and Method: 61 patients with metastatic malignant melanoma (affecting the lymph node or other distant sites) were selected. Patient data regarding age at the time of diagnosis, sex, metastatic site (lymph node, distant metastasis or both) and primary tumour site were obtained from the hospital's database. Tissue samples containing at least $30 \%$ tumour cells were isolated from the specimens of 61 patients (24 samples from primary tumours and 37 from metastatic foci) for BRAF analysis. Comparisons between the BRAF V600 mutation and clinicopathological and histopathological features were performed.

Results: BRAF V600 mutation was detected in 34 (55.7\%) patients. The subtype was BRAF V600E in 22 (64.7\%) patients, BRAF V600K in 11(32.4\%) patients and BRAF V600R in 1(2.9\%) patient. The crucial results of the present study may be summarized as follows: i) BRAF V600 mutation was more common in older patients and tumors with BRAF V600 mutation revealed necrosis and LVI more commonly than wild-type tumors, ii) BRAF V600K mutation was more common in older patients and BRAF V600K mutated tumors exhibited ulceration more commonly than tumors with BRAF V600E mutation (close to significant).

Conclusion: The BRAF V600 mutation may have interactions with prognostic clinicoptahological features of melanoma including necrosis and lymphovascular invasion. V600K mutation may be more common than expected and may have different associations with properties of the tumor such as tumor ulceration and patient age. Investigation of the mutated subtype of the BRAF gene may therefore reveal more detailed data about the management of melanoma and may also prevent missing of candidates for BRAF inhibitor therapies.

Key Words: Malignant melanoma, BRAF mutation, Clinicopathological features

\section{INTRODUCTION}

Melanoma has a poor prognosis $(1,2)$. Davies et al. introduced the idea of molecular alterations as an alternative to ultraviolet (UV) signature, particularly with $B R A F$ (v-raf murine sarcoma viral oncogene B) V600 mutations (3), marking a milestone in the treatment of previously-incurable melanoma patients. BRAF V600 is the most common mutation in melanoma, reportedly accounting for 50 to $70 \%$ of melanoma cases $(3,4)$. The $B R A F$ gene encodes a serine/threonine protein kinase, which regulates the RAF-RAS-mitogene-activated protein kinase (MAPK)-extracellular signal-regulated kinase (ERK) signaling pathway, which impacts cellular proliferation, differentiation and survival (5). The BRAF V600E mutation constitutes more than $80 \%$ of $B R A F$ mutations, and it reflects the substitution of valine to

(Turk Patoloji Derg 2018, 34:134-142)

Received : 28.06.2017 Accepted : 15.01.2018 glutamic acid (Val600Glu). The BRAF V600E mutation causes a continuous downstream signaling of the MAPK pathway and ERK activation. Consequently, the affected cells proliferate and acquire survival advantages. Other BRAF mutations include V600K (1798 1799 GT > AA; 5\% to 6\%; valine to lysine), V600R (1798 $1799 \mathrm{GT}>\mathrm{AG}$; $1 \%$; valine to arginine), V600E2 (1799 1800 AG > AA; 0.7\%) and V600D (1799 1800 AG > AT). Other rare mutations affecting various codons of the $B R A F$ gene have also been described $(1,4,6)$. Although the BRAF V600K mutation is said to be rare, a few recent papers have reported an occurrence rate of this mutation as high as $20 \%$ in some populations (6-8).

Accumulated data about the molecular alterations in melanoma led to the development of selective kinase inhibitors to target the activating mutations in the MAPK

Correspondence: Nuray CAN

Department of Pathology, Trakya University, Faculty of Medicine

Balkan Campus, 22O3O, EDİRNE, TURKEY

E-mail: nuraycan@ymail.com Phone: +90 284235 76 41-1534 
pathway, particularly $B R A F$, for patients with unresectable disease and/or distant metastasis. Although these therapies have evoked dramatic responses from many patients, resistance to them has limited the success of these drugs for many others $(9,10)$. However, one of the BRAF inhibitors has been used for both BRAF V600E and BRAF V600K, with reported overall V600K response lower than that of V600E $(11,12)$. Shorter survival and shorter intervals between initial diagnosis and metastasis have been reported for $\mathrm{V} 600 \mathrm{~K}$ as compared to $\mathrm{V} 600 \mathrm{E}$ as well $(1,6)$. Some studies investigating the differences between the V600K and V600E mutations reveal that age, gender and primary tumour site may differ according to the mutation subtype and changing amino acids $(1,6)$.

The Cancer Genome Atlas Network (10) has defined genomic classifications of melanoma as BRAF subtype, RAS subtype, NF-1 subtype and Triple-Wild subtype and defined the transcriptomic classifications of melanoma in the following subclasses: 'immune', 'keratin' and 'microphthalmia-associated transcription factor (MITF)Low'. Transcriptomic subclasses are said to have a possible impact on prognosis-for example, better prognosis in the immune subclass-whereas the genomic subtype does not effect the clinical outcome (10).

The present study aimed to investigate two main issues. First, the study investigated whether the BRAF mutation is related to the following clinicopathological features of melanoma: gender, age at presentation, histological tumour type, Breslow's thickness, total lymphocytic score, necrosis, ulceration, tumour cell type, cellularity, tumour fibrosis, lymphovascular invasion (LVI), perineural invasion (PNI), microsatellitosis and in-transit metastasis. Second, the study investigated whether these clinicopathological features differ according to the subtype of the BRAF mutation, with a focus on the most common subtypes, V600E and V600K.

\section{MATERIAL and METHODS}

\section{Patient Selection}

The medical reports of patients with cutaneous malignant melanoma who presented at the Department of Pathology (Trakya University Medical Faculty) were reviewed between November 2012 and November 2016. 61 patients with metastatic disease (affecting the lymph node or other distant sites) were selected. Patient data regarding age at the time of diagnosis, sex, metastatic site (lymph node, distant metastasis or both) and primary tumour site were obtained from the hospital's database. As most of the subjects had been referred to the Oncology Hospital of Trakya University based on pathological reports from other centres, the primary tumour site was known in only 35 of the 61 patients. Patients with available specimens of the primary tumour site were included in the study, totalling 24 patients. Specimens of metastatic foci were available for 37 of the patients. Histopathological features were evaluated for the 24 patients with pathological specimens of the primary tumour available. In all, 24 patients were included in the comparisons between the BRAF V600 mutation and clinicopathological and histopathological features. Haematoxylin and eosin-stained slides of the primary tumour were re-evaluated by a pathologist (N.C.) who was blinded to the original pathological diagnosis of the slide, the clinical data and the prognostic data. The study protocol was approved by the ethics committee of the university hospital (Ethics Number: TUTF-BAEK2016/174).

\section{Clinicopathological Criteria}

- Breslow's thickness
o $<1 \mathrm{~mm}$
o $\quad 1.01-2 \mathrm{~mm}$
o $\quad 2.01-4 \mathrm{~mm}$
o $>4 \mathrm{~mm}$

- Total lymphocytic score (TLS) (Figure 1A) (with a 6-tiered system) (10)

- Tumour necrosis (absent or present) (Figure 1B)

- Percentage of tumour necrosis

- Tumour ulceration (absent or present) (Figure 1C)

- Percentage of tumour ulceration

- Number of mitoses per $\mathrm{mm}^{2}$ (as numbers) (Figure 1D)

- Type of tumour cells

o Epitheloid

o Spindled

o Mixed epitheloid and spindled

- Tumour content (as percentage of nucleated cells in a target area)

- Tumour fibrosis
o Absent
o Mild
o Intermediate
o Significant

- LVI (absent or present)

- PNI (absent or present)

- Microsatellitosis (absent or present)

- In-transit metastasis (absent or present) 

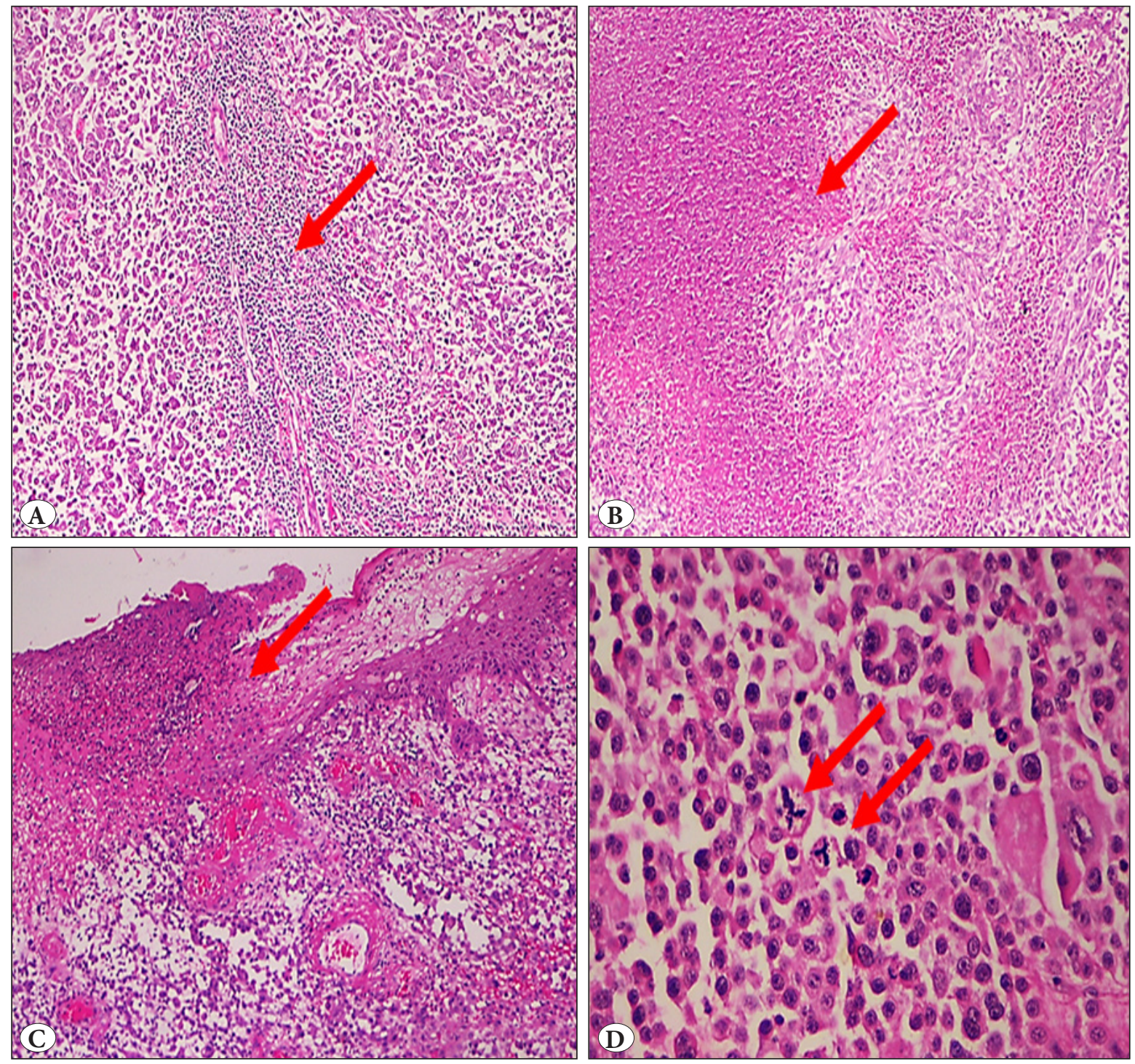

Figure 1: A) Lymphocytic infiltration corresponding Score 4 (arrows) (H\&E; x100). B) Geographical necrosis (arrows) (H\&E; x100), C) Tumor ulceration associated with granulation tissue (arrows) (H\&E; x200), D) Mitotic figures (arrows) (H\&E; $\mathrm{x} 400)$.

- Histological tumour type

o Acral lentiginous melanoma (ALM)

o Lentigo maligna melanoma (LMM)

o Nodular melanoma (NM)

o Superficial spreading melanoma (SSM)

\section{Total Lymphocytic Score}

Lymphocyte distribution and lymphocyte density were evaluated as follows.

Lymphocyte distribution:

$0=$ no lymphocytes within the tissue

$1=$ lymphocytes present in $<25 \%$ of the crosssectional tissue area
$2=$ lymphocytes present in 25 to $50 \%$ of the tissue $3=$ lymphocytes present in $>50 \%$ of the tissue

Lymphocyte density:

$$
\begin{aligned}
& 0=\text { absent } \\
& 1=\text { mild } \\
& 2=\text { moderate } \\
& 3=\text { severe }
\end{aligned}
$$

The sum of the scores obtained from these evaluations were categorized as TLS into a six-tiered classification system (10). 


\section{BRAF Mutation Analysis}

Tissue samples containing at least 30\% tumour cells were isolated from the specimens of 61 patients (24 samples from primary tumours and 37 from metastatic foci) for $B R A F$ analysis. Then, DNA purification was performed, using a nucleic acid isolation kit for paraffin-embedded tissue (QIAamp ${ }^{\circledR}$ DNA FFPE Tissue Kit, QIAGEN (Hilden, Germany) Catologue No. 56404, EZ1 ${ }^{\circ}$ DNA Tissue Kit, QIAGEN 953034, PAXgene ${ }^{\oplus}$ Tissue Containers, QIAGEN (Hilden, Germany) Catalogue No. 765112, PAXgene Tissue DNA Kit, QIAGEN (Hilden, Germany) Catalogue No. 767134). Following the polymerase chain reaction procedures, pyrosequencing analyses were performed on PyroMarkQ24, using sequencing primers including the Seq Primer BRAF 600 or Seq Primer BRAF 464-469 (QIAGEN (Hilden, Germany) Catalogue No. 970470) for $B R A F$. The BRAF V600 mutation (absent or present) and subtype (BRAF 600E, BRAF $600 \mathrm{~K}$ or BRAF 600R) were noted (Figure 2).

\section{Statistical Analyses}

Results were shown as numbers and percentages or as means \pm standard deviation in defining parameters such as age, percentage of necrosis, percentage of ulceration, percentage of tumour cells and mitosis. The chi-squared tests (Pearson's, Yates' or Fisher's exact test) and nonparametric tests (Mann Whitney test) were used in comparisons of clinicopathological features according to BRAF V600 mutation status (wild-type or mutated). Clinicopathological features were also compared according to $B R A F$ V600 mutation subtype (BRAF V600E and BRAF V600K). The single patient with the BRAF V600R subtype was excluded from the comparisons. A $\mathrm{p}$ value $<0.05$ was considered as statistically significant. The SPSS 20.0 software (IBM SPSS Inc., Chicago, IL, USA) was used for statistical analysis.

\section{RESULTS}

\section{Clinicopathological Features}

The clinicopathological features of the 61 patients in the group are presented in Table I. The mean age of the patients was $62.87 \pm 12.19$. Of the 61 subjects, 34 (55.7\%) were male and 27 (44.3\%) female. The BRAF V600 mutation was detected in $34(55.7 \%)$ of the patients. The subtype was BRAF V600E in $22(64.7 \%), B R A F$ V600K in 11 (32.4\%) and BRAF V600R in $1(2.9 \%)$ of the patients. A sample of the primary tumour site was available in $35(57.4 \%)$ of the subjects, taken from the head and neck in 17 (48.6\%), from
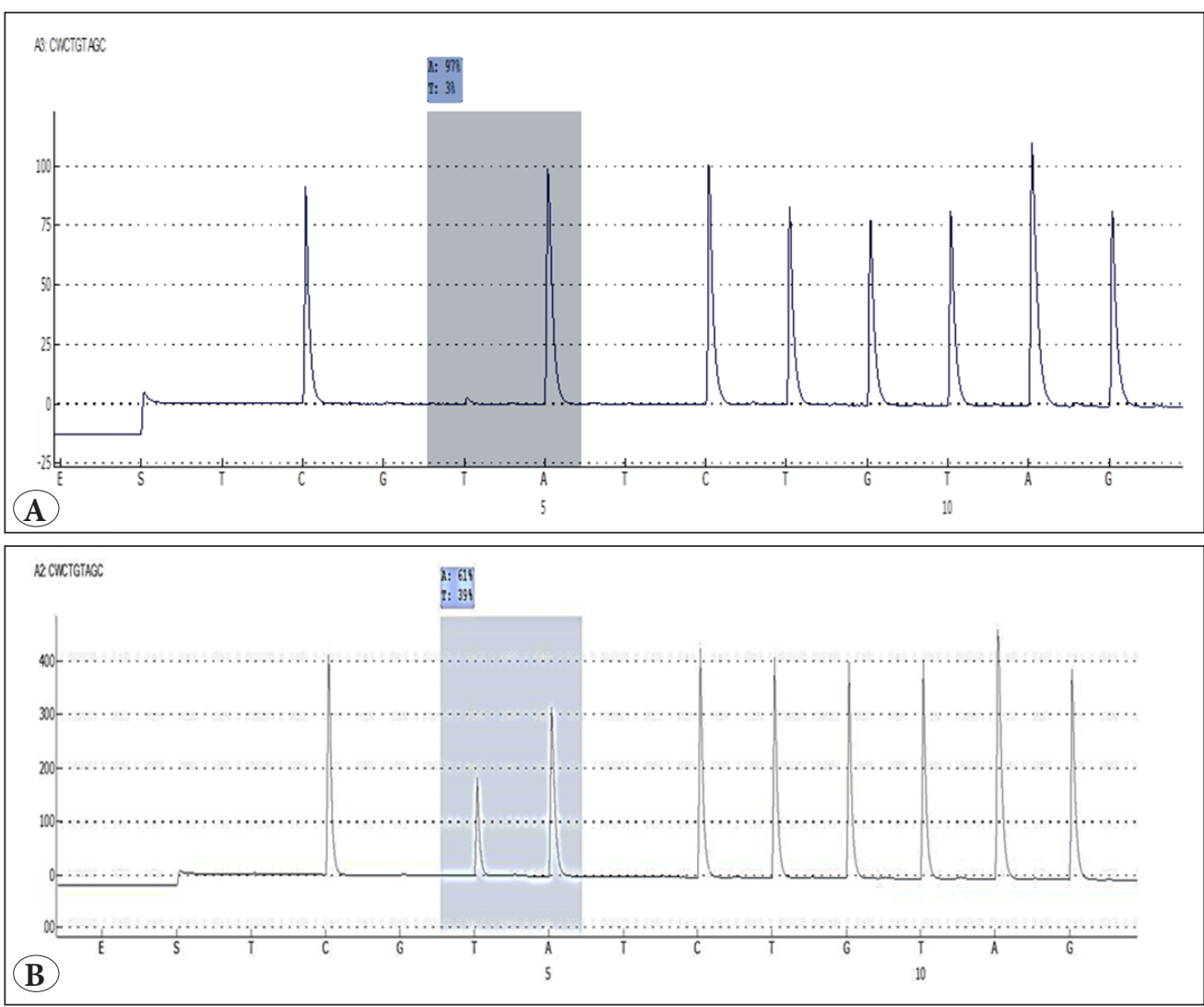

Figure 2: Results of mutation analysis by pyrosequencing assay, A) Wild-type $B R A F$, B) BRAF V600E mutation. 
the trunk in 4 (11.4\%), from the extremities in $12(34.3 \%)$ and from other sites in 2 (5.7\%). Breslow's thickness was $1.01-2 \mathrm{~mm}$ in 2 (8.3\%), 2.01-4 $\mathrm{mm}$ in $5(20.8 \%)$ and $>4$ $\mathrm{mm}$ in $17(70.8 \%)$ of the patients. No patients had Breslow's thickness as $\leq 1 \mathrm{~mm}$. The total lymphocyte score was 2 in 11 (45.8\%) of the subjects, 3 in 2 (8.3\%) of them, 4 in $5(20.8 \%)$, 5 in $3(12.5 \%)$ and 6 in $3(12.5 \%)$. Necrosis was detected in $5(20.8 \%)$ of the patients. The tumour was ulcerated in 14 (58.3\%) of the cases. The dominant tumour cell type was epithelioid in 16 (66.6\%), mixed epithelioid and spindled in $6(25.0 \%)$ of the patients and spindled in $2(8.3 \%)$ of the patients. Tumour fibrosis was mild in $9(37.5 \%)$ of the patients, intermediate in $8(33.3 \%)$ and significant in $4(16.6 \%)$. LVI was seen in $16(66.6 \%)$, whereas PNI was detected in $2(8.3 \%)$ of the subjects. Microsatellitosis and intransit metastasis were present in 6 (25.0\%) of the patients. The histological tumour type was ALM in 3 (12.5\%), LMM in $4(16.6 \%)$ and NM in $17(70.8 \%)$ of the patients. None of the patients had the SSM type. The mean number of mitoses per $\mathrm{mm}^{2}$ was $7.65 \pm 5.00$.

\section{Comparisons of Clinicopathological Features According to BRAF V600 Mutation Status}

The comparisons of clinicopathological features according to the status of BRAF V600 mutation are presented in Table I. The median age was $62.6 \pm 12.0$ years in patients with the $B R A F \mathrm{~V} 600$ mutation, whereas it was $65.0 \pm 13.8$ in patients with wild-type BRAF V600. Necrosis was significantly more common in mutated tumours $(\mathrm{p}=0.039)$ and the percentage of necrosis in a tumour was significantly higher in mutated tumours $(\mathrm{p}=0.037)$. Tumours with the BRAF V600 mutation exhibited significantly higher rates of LVI than wild-type tumours ( $\mathrm{p}=0.031$ ). There was no significant correlation between the BRAF V600 mutation status and other clinicopathological features. The most common histological tumour type was NM in BRAF V600-mutated tumours; however, this was not statistically significant.

\section{Comparisons of Clinicopathological Features According to $B R A F$ V600 Mutation Subtype (BRAF V600E or BRAF V600K)}

The comparisons of clinicopathological features according to BRAF V600 mutation subtype are presented in Table I. There was no statistically significant correlation between clinicopathological features and mutated BRAF V600 subtype. Certain trends arose but were not statistically significant. For example, the BRAF V600K mutation was more common in older patients than BRAF V600E (74.0 \pm 12.7 and $61.5 \pm 11.1$, respectively; $\mathrm{p}=0.064)$. Ulceration was more common in tumours with the BRAF V600K mutation $(\mathrm{p}=0.094)$, and the percentage of ulceration in tumours was higher in BRAF V600K-mutated tumours ( $\mathrm{p}$ $=0.080$ ) than BRAF V600E. Tumours with BRAF V600K were more commonly located in the head and neck region than those with BRAF V600E. The single patient with LMM exhibited BRAF V600K mutation.

\section{DISCUSSION}

Melanoma had one of the worst prognoses of skin tumours prior to the introduction of molecular alterations as an alternative to ultraviolet (UV) signature, particularly for BRAF V600 mutations, by Davies et al. (1-3). BRAF is the most commonly mutated gene in melanoma, accounting for 50 to $70 \%$ of melanomas $(3,4)$. Its most common subtype is the BRAF V600E mutation, followed by $\mathrm{V} 600 \mathrm{~K}(1,4,6)$. The present study investigates two main issues: first, whether the BRAF mutation correlates with clinicopathological features of melanoma and second, whether these clinicopathological features differ according to the mutated BRAF subtype V600E or V600K.

The results of the present study are as follows. The BRAF V600 mutation may be more common in older patients, and tumours with the BRAF V600 mutation may reveal necrosis more commonly and with higher percentages and may reveal LVI more commonly than wild-type tumours. Furthermore, the BRAF V600K mutation may be more common in older patients and BRAF V600K-mutated tumours may have ulceration more commonly and with higher percentages than tumours with the BRAF V600E mutation.

The data about BRAF V600 mutation which was accumulated following the discovery of this mutation in cancer by Davies et al. (3) revealed that at least half of malignant melanomas (50 to 70\%) may exhibit mutations in the BRAF V600 gene $(1,2,7,10,13-16)$ The BRAF V600E mutation constitutes more than $80 \%$ of $B R A F$ mutations, and other BRAF mutations include V600K (1798 1799 GT > AA; 5\% to 6\%; valine to lysine), V600R (1798 $1799 \mathrm{GT}>$ AG; 1\%; valine to arginine), V600E2 (1799 1800 AG > AA; $0.7 \%)$ and V600D (1799 $1800 \mathrm{AG}>\mathrm{AT})(1,4,6)$. Although it is said that the BRAF V600K mutation is rare, a few recent papers report higher rates of this mutation (20 to $44 \%)$ in some populations $(6-8,15)$. In the present study, the BRAF V600E mutation was the most common subtype of the BRAF gene, followed by the BRAF V600K mutation.

The alignment of the mutated subtypes was compatible with previously-reported results. However, the rate of $B R A F$ V600K mutation found was higher than that in most of the previously-reported results (Table II) $(1,6,10,17)$. 
Table I: Clinicopathological features in the study group and comparisons of clinicopathological features according to the status of BRAF V600 mutation

\begin{tabular}{|c|c|c|c|c|c|c|c|c|c|}
\hline Parameters & & & Total & $\begin{array}{c}\text { BRAF } \\
\text { Wild-type }\end{array}$ & $\begin{array}{c}\text { BRAF } \\
\text { Mutated }\end{array}$ & $\mathbf{p}$ & $\begin{array}{l}\text { BRAF } \\
\text { V600E }\end{array}$ & $\begin{array}{l}\text { BRAF } \\
\text { V600K }\end{array}$ & $\mathbf{p}$ \\
\hline \multirow{2}{*}{ Gender } & Male & $34(55.7)$ & \multirow{2}{*}{61} & $13(38.2)$ & $21(61.8)$ & \multirow[t]{2}{*}{0.312} & $14(70.0)$ & $6(30.0)$ & \multirow[t]{2}{*}{0.714} \\
\hline & Female & $27(44.3)$ & & $14(51.9)$ & $13(48.1)$ & & $8(61.5)$ & $5(38.5)$ & \\
\hline $\begin{array}{l}\text { Median Age } \\
\text { (Years) }\end{array}$ & & $\begin{array}{c}66 \\
(35-86) \\
\end{array}$ & & $66(35-86)$ & $\begin{array}{c}62.5 \\
(37-83) \\
\end{array}$ & $0.420^{\mathrm{a}}$ & $\begin{array}{c}61.5 \\
(37-77)\end{array}$ & $\begin{array}{c}74 \\
(45-83)\end{array}$ & $0.064^{\mathrm{a}}$ \\
\hline \multirow{3}{*}{ Metastatic site } & LNM & $23(37.7)$ & \multirow{3}{*}{61} & $9(33.3)$ & $14(41.2)$ & \multirow[t]{2}{*}{0.172} & $4(50.0)$ & $2(33.3)$ & 0.104 \\
\hline & $\mathrm{DM}$ & $24(39.3)$ & & $9(33.3)$ & $15(44.1)$ & & $4(50.0)$ & $4(66.6)$ & \\
\hline & LNM+DM & $14(23.0)$ & & $9(33.3)$ & $5(14.7)$ & & $0(0.0)$ & $0(0.0)$ & \\
\hline \multirow{4}{*}{ Primary site } & Head and neck & $17(48.6)$ & \multirow{4}{*}{35} & $5(29.4)$ & $12(70.6)$ & \multirow{4}{*}{0.132} & $5(45.5)$ & $6(54.5)$ & \multirow{4}{*}{0.279} \\
\hline & Trunk & $4(11.4)$ & & $3(75.0)$ & $1(25.0)$ & & $1(100.0)$ & $0(0.0)$ & \\
\hline & Extremities & $12(34.3)$ & & $7(58.3)$ & $5(41.7)$ & & $4(80.0)$ & $1(20.0)$ & \\
\hline & Other sites & $2(5.7)$ & & $0(0.0)$ & $2(100.0)$ & & $2(10.0)$ & $0(0.0)$ & \\
\hline \multirow{4}{*}{$\begin{array}{l}\text { Breslow's } \\
\text { thickness }\end{array}$} & $\leq 1 \mathrm{~mm}$ & $0(0.0)$ & \multirow{4}{*}{24} & $0(0.0)$ & $0(0.0)$ & \multirow{4}{*}{0.213} & $0(0.0)$ & $0(0.0)$ & \multirow{4}{*}{1.000} \\
\hline & $1.01-2 \mathrm{~mm}$ & $2(8.4)$ & & $2(100.0)$ & $0(0.0)$ & & $0(0.0)$ & $0(0.0)$ & \\
\hline & $2.01-4 \mathrm{~mm}$ & $5(20.8)$ & & $2(40.0)$ & $3(60.0)$ & & $2(66.7)$ & $1(33.3)$ & \\
\hline & $>4 \mathrm{~mm}$ & $17(70.8)$ & & $6(35.3)$ & $11(64.7)$ & & $6(54.5)$ & $5(45.5)$ & \\
\hline \multirow{6}{*}{$\begin{array}{l}\text { Total } \\
\text { lymphocytic } \\
\text { score }\end{array}$} & 1 & $0(0.0)$ & \multirow{6}{*}{24} & $0(0.0)$ & $0(0.0)$ & \multirow{6}{*}{0.337} & $0(0.0)$ & $0(0.0)$ & \multirow{6}{*}{0.727} \\
\hline & 2 & $11(45.8)$ & & $5(45.5)$ & $6(54.5)$ & & $4(80.0)$ & $2(20.0)$ & \\
\hline & 3 & $2(8.3)$ & & $0(0.0)$ & $2(100.0)$ & & $0(0.0)$ & $2(100.0)$ & \\
\hline & 4 & $5(20.8)$ & & $1(20.0)$ & $4(80.0)$ & & $2(50.0)$ & $2(50.0)$ & \\
\hline & 5 & $3(12.5)$ & & $2(66.7)$ & $1(33.3)$ & & $1(100.0)$ & $0(0.0)$ & \\
\hline & 6 & $3(12.5)$ & & $2(60.0)$ & $1(40.0)$ & & $1(100.0)$ & $0(0.0)$ & \\
\hline \multirow{2}{*}{ Necrosis } & Absent & $19(79.2)$ & \multirow{2}{*}{24} & $9(47.4)$ & $10(52.6)$ & & $7(70.0)$ & $3(30.0)$ & $1000^{\mathrm{b}}$ \\
\hline & Present & $5(20.8)$ & & $1(18.2)$ & $4(81.8)$ & & $2(50.0)$ & $2(50.0)$ & \\
\hline $\begin{array}{l}\text { Percentage of } \\
\text { tumor necrosis }\end{array}$ & & $0(0-60)$ & & $0(0-50)$ & $0(0-60)$ & $0.037^{a}$ & $0(0-60)$ & $1(0-50)$ & $0.832^{\mathrm{a}}$ \\
\hline Ullceration & Absent & $10(41.7)$ & 24 & $4(40.0)$ & $6(60.0)$ & $0615 \mathrm{~b}$ & $5(83.3)$ & $1(16.7)$ & $0094^{\mathrm{b}}$ \\
\hline viceration & Present & $14(58.3)$ & 24 & $6(42.9)$ & $8(57.1)$ & & $3(37.5)$ & $5(62.5)$ & $0.094^{\circ}$ \\
\hline Lymphovascular & Absent & $8(33.3)$ & 24 & $8(100.0)$ & $0(0.0)$ & 0.031 & - & - & \\
\hline invasion & Present & $16(66.6)$ & 24 & $2(12.5)$ & $14(87.5)$ & 0.001 & $10(71.4)$ & $4(28.6)$ & calculated \\
\hline Perineural & Absent & $22(91.7)$ & 24 & $10(45.5)$ & $12(54.5)$ & & $6(50.0)$ & $6(50.0)$ & \\
\hline invasion & Present & $2(8.3)$ & 24 & $0(0.0)$ & $2(100.0)$ & 1.000 & $1(50.0)$ & $1(50.0)$ & $0.3 / 5^{\circ}$ \\
\hline Microsatellitosis & Absent & $18(75.0)$ & 24 & $9(50.0)$ & $9(50.0)$ & $0.251^{t}-x^{2}$ & $6(66.6)$ & $3(33.3)$ & $0.266^{\mathrm{b}}$ \\
\hline Nircrosatemtosis & Present & $6(25.0)$ & 24 & $1(16.7)$ & $5(83.3)$ & 0.20 & $3(60.0)$ & $2(40.0)$ & 0.200 \\
\hline In -transit & Absent & $18(75.0)$ & 24 & $9(50.0)$ & $9(50.0)$ & $0.179^{1}$ & $6(66.6)$ & $3(33.3)$ & $0.103^{b}$ \\
\hline metastasis & Present & $6(25.0)$ & 24 & $1(16.7)$ & $5(83.3)$ & $0.1 / 9^{\circ}$ & $3(60.0)$ & $2(40.0)$ & \\
\hline & ALM & $3(12.5)$ & & $2(66.7)$ & $1(33.3)$ & & $1(100.0)$ & $0(0.0)$ & \\
\hline Histological & LMM & $4(16.6)$ & 24 & $3(75.0)$ & $1(25.0)$ & 0161 & $0(0.0)$ & $1(100.0)$ & 0.244 \\
\hline tumor type & NM & $17(70.8)$ & 24 & $5(29.4)$ & $12(70.6)$ & 0.161 & $7(58.3)$ & $5(41.7)$ & \\
\hline & SSM & $0(0.0)$ & & $0(0.0)$ & $0(0.0)$ & & $0(0.0)$ & $0(0.0)$ & \\
\hline Mitosis & & $\begin{array}{c}5.9 \\
(1.1-24.6)\end{array}$ & & $\begin{array}{c}5.2 \\
(1.1-15.6)\end{array}$ & $\begin{array}{c}7.1 \\
(2.9-24.6)\end{array}$ & $0.399^{\mathrm{a}}$ & $\begin{array}{c}6.7 \\
(2.9-14.9)\end{array}$ & $\begin{array}{c}7.8 \\
(4.2-24.6)\end{array}$ & $0.204^{\mathrm{a}}$ \\
\hline
\end{tabular}

LNM: Lymph node metastasis, DM: Distant metastasis, ALM: Acral lentiginous melanoma, LMM: Lentigo maligna melanoma. NM: Nodular melanoma, SSM: Superficial spreading melanoma. Data regarding the features except age, percentage of necrosis, percentage of ulceration, percentage of tumor cells and mitosis are presented as numbers and percentages (n (\%)).

${ }^{a}$ : Median and range, Mann Whitney test. ${ }^{\text {b }}$ : Fisher's exact test. 
It should be noted that data gathered from closer geographical regions to that of the present study showed similar results, including higher rates of V600K mutations $(15,18,19)$. The difference in the rate of V600K mutations may be due to the sequencing method (sequencing the entire exon 15 genome) used in other studies. It may also be due to geographical properties, particularly differences in UV exposure. Future studies involving larger case series and investigating the impact of environmental factors may provide more definite results regarding the rate of V600K mutations. Also, sequencing the entire exon 15 genome may prevent overlooking BRAF V600-mutated patients and depriving those patients of $B R A F$ inhibitor therapies.

Many studies have revealed that the BRAF mutation is associated with younger age, nodular or superficial spreading histological type, tumour location on the trunk and intermittent sun exposure $(5,15,17,20)$. Also, a study by Hughahl et al. (22) revealed the association between higher rates of BRAF V600 immunohistochemistry expression and increased tumour thickness, presence of ulceration and higher rates of mitosis. Conversely, several papers have declared that the BRAF V600 mutation has no impact on clinicopathological features or survival (22-26). Although there was no significant correlation in the present study, the patients with the BRAF V600 mutation were younger than the patients with wild-type $B R A F$, and NM was detected more commonly in BRAF V600-mutated patients.
Furthermore, significant correlations were detected between BRAF mutation and both tumour necrosis and LVI. These findings may be due to the nature of the study group, namely that all the cases had metastatic melanoma, which is expected to present adverse prognostic features. Furthermore, differences between previous studies and the present study may be due to the absence of investigation of LVI and necrosis in many of the above-mentioned studies. However, various molecular alterations accompanying the $B R A F$ V600 mutation may also be features of an ordinary nevus, such as promoter mutations of telomerase reverse transcriptase (TERT) $(27,28)$; mutations in NRAS, PTEN, CDK2NA, STK19, KIT, GNAQ, GNA11 and NF 1 genes (29-31) or undetected interactions between the BRAF V600 mutation and other signaling pathways (26). Further studies on genotypic and phenotypic alterations in specimens of primary tumours obtained from both metastatic and nonmetastatic patients may provide more information about the impact of the BRAF mutation on prognostic features of melanoma.

A few studies comparing clinicopathological features according to mutated subtype-particularly the most common subtypes, BRAF V600E and BRAF V600K-have reported that the BRAF V600K mutation correlates with older age, male gender, head and neck localization of the primary tumour, higher degree of cumulative sun exposure, shorter interval between the initial diagnosis and the first

Table II: An overview of studies presenting data about BRAF mutation status in cutaneous melanoma from different regions of Turkey

\begin{tabular}{|c|c|c|c|c|c|c|c|c|c|}
\hline Study & Year/Region (City) & $\begin{array}{c}\text { Median } \\
\text { Age } \\
\text { (years) }\end{array}$ & $\begin{array}{c}\text { Female/ } \\
\text { male }\end{array}$ & $\begin{array}{c}\text { Sample } \\
\text { type }\end{array}$ & Procedure & $\begin{array}{c}\text { BRAF } \\
\text { Mutation } \\
\text { Rate (\%) }\end{array}$ & $\begin{array}{c}\text { BRAF } \\
\text { V600E } \\
(\%)\end{array}$ & $\begin{array}{c}\text { BRAF } \\
\text { V600K } \\
(\%)\end{array}$ & $\begin{array}{l}\text { Others } \\
(\%)\end{array}$ \\
\hline $\begin{array}{l}\text { Akman, } \\
\text { (19) }\end{array}$ & 2015/West (Izmir) & 51.5 & $26 / 24$ & $\begin{array}{c}\text { Primary } \\
\text { tumor }\end{array}$ & $\begin{array}{l}\text { Microarray- based } \\
\text { molecular methods }\end{array}$ & 42 & 71.4 & 14.3 & 14.3 \\
\hline $\begin{array}{l}\text { Yilmaz, } \\
\text { (30) }\end{array}$ & $\begin{array}{l}\text { 2015/Northwestern } \\
\text { (Istanbul) }\end{array}$ & 62.1 & $17 / 30$ & $\begin{array}{l}\text { Primary } \\
\text { tumor }\end{array}$ & Sanger sequencing & 29.8 & 85.7 & 7.1 & 7.1 \\
\hline $\begin{array}{l}\text { Yaman, } \\
\text { (15) }\end{array}$ & 2015/West (Izmir) & 59.9 & $46 / 60$ & $\begin{array}{l}\text { Primary } \\
\text { tumor }\end{array}$ & $\begin{array}{c}\text { Real-time } \\
\text { PCR- based PCR- } \\
\text { Array }\end{array}$ & 42.5 & 53.3 & 44.4 & 2.2 \\
\hline $\begin{array}{l}\text { Yaman, } \\
\text { (18) }\end{array}$ & 2016/West (Izmir) & 52.56 & $19 / 29$ & $\begin{array}{l}\text { Primary / } \\
\text { metastatic } \\
\text { tumor }\end{array}$ & Pyrosequencing & 78.1 & 80.0 & 13.3 & 6.6 \\
\hline $\begin{array}{l}\text { Sener, } \\
(20)\end{array}$ & $\begin{array}{c}\text { 2017/Central } \\
\text { Anatolia (Ankara) }\end{array}$ & 59.6 & $47 / 51$ & $\begin{array}{l}\text { Primary / } \\
\text { metastatic } \\
\text { tumor }\end{array}$ & $\begin{array}{c}\text { Real-time } \\
\text { PCR assay and } \\
\text { pyrosequencing }\end{array}$ & 29.2 & 78.6 & 21.4 & 0.0 \\
\hline $\begin{array}{l}\text { Can, } \\
\text { (Present } \\
\text { study) }\end{array}$ & $\begin{array}{l}\text { 2017/Europe/ } \\
\text { Northwestern } \\
\text { Turkey (Edirne) } \\
\end{array}$ & 63.0 & $27 / 34$ & $\begin{array}{l}\text { Primary / } \\
\text { metastatic } \\
\text { tumor }\end{array}$ & Pyrosequencing & 55.7 & 64.7 & 32.4 & 2.9 \\
\hline
\end{tabular}

PCR: Polymerase chain reaction. 
metastasis and shorter survival of stage IV disease $(1,6)$. In the present study, no significant differences were found between the BRAF V600K mutation and the BRAF V600E mutation in terms of clinicopathological features. The $B R A F$ V600K mutation was more common in older patients and was more common in tumours exhibiting ulceration, although these results were not statistically significant. Most of the tumours with BRAF V600K mutation were located in the head and neck region, and the single patient with LMM presented with BRAF V600K mutation. These results were compatible with those of previous studies, with the exception of the result concerning ulceration. Menzies et al. (6) investigated the impact of cumulative, suninduced damage (or grade of solar elastosis) on BRAF V600 mutation subtypes and reported that the impact is higher in patients with the BRAF V600K mutation than in patients with the BRAF V600E mutation. The present study did not evaluate the effect of sun-induced damage by mutation subtype. Future studies investigating the histological impact of sun-induced damage and the molecular signature of UV exposure accompanied by the BRAF mutation in larger groups are recommended to provide crucial information on this matter.

Bucheit et al. (1) state that metastases emerging from V600K mutant melanomas have a more aggressive phenotype than primary tumours with the BRAF V600E mutation despite the absence of a significant correlation between the mutation status and either ulceration or Breslow's thickness. The present study investigated the relationships between the properties of primary tumour and mutation status. The correlation found between the BRAF V600K mutation and tumour ulceration in the small study group was not statistically significant. Studies investigating the clinicopathological and molecular features in both primary tumour sites and metastatic sites and which include data from clinical follow-ups may reveal clues in predicting the clinical behavior of tumours and the phenotype of metastatic tumours.

The present study has some limitations. First, the number of cases included in the study is low, and the study presents data from a single medical centre in a limited geographical area. Second, data from clinical-follow ups could not be presented in the study. However, the results do provide data about the mutation profile of melanoma occurring in the limited geographical region in southeastern Europe.

In conclusion, detection of the BRAF V600 mutation may signal prognostic, clinicoptahological features of malignant melanoma, including necrosis and LVI as well as provide information pertinent to patient selection for $B R A F$-inhibitor therapies. The subtype of the BRAF V600 mutation may influence the properties of a tumour, such as tumour ulceration and patient age. Furthermore, rare subtypes of the BRAF V600 mutation, particularly V600K, may not be as rare as once thought. Further investigation of the mutated subtypes of the BRAF gene in melanoma may reveal more detailed data about melanoma management, and sequencing entire subtypes may prevent overlooking candidates for BRAF-inhibitor therapies.

\section{CONFLICT of INTEREST}

The authors declare no conflict of interest.

\section{REFERENCES}

1. Bucheit AD, Syklawer E, Jakob JA, Bassett RL Jr, Curry JL, Gershenwald JE, Kim KB, Hwu P, Lazar AJ, Davies MA. Clinical characteristics and outcomes with specific BRAF and NRAS mutations in patients with metastatic melanoma. Cancer. 2013;119:3821-9.

2. Rajkumar S, Watson IR. Molecular characterisation of cutaneous melanoma: Creating a framework for targeted and immune therapies. Br J Cancer. 2016;115:145-55.

3. Davies H, Bignell GR, Cox C, Stephens P, Edkins S, Clegg S, Teague J, Woffendin H, Garnett MJ, Bottomley W, Davis N, Dicks E, Ewing R, Floyd Y, Gray K, Hall S, Hawes R, Hughes J, Kosmidou V, Menzies A, Mould C, Parker A, Stevens C, Watt S, Hooper S, Wilson R, Jayatilake H, Gusterson BA, Cooper C, Shipley J, Hargrave D, Pritchard-Jones K, Maitland N, ChenevixTrench G, Riggins GJ, Bigner DD, Palmieri G, Cossu A, Flanagan A, Nicholson A, Ho JW, Leung SY, Yuen ST, Weber BL, Seigler HF, Darrow TL, Paterson H, Marais R, Marshall CJ, Wooster R, Stratton MR, Futreal PA. Mutations of the BRAF gene in human cancer. Nature. 2002;417:949-54.

4. Bello DM, Ariyan CE, Carvajal RD. Melanoma mutagenesis and aberrant cell signaling. Cancer Control. 2013;20:261-81.

5. Junkins-Hopkins JM. Malignant melanoma: Molecular cytogenetics and their implications in clinical medicine. J Am Acad Dermatol. 2010;63:329-32.

6. Menzies AM, Haydu LE, Visintin L, Carlino MS, Howle JR, Thompson JF, Kefford RF, Scolyer RA, Long GV. Distinguishing clinicopathologic features of patients with V600E and V600K BRAF-mutant metastatic melanoma. Clin Cancer Res. 2012;18:3242-9.

7. Long GV, Menzies AM, Nagrial AM, Haydu LE, Hamilton AL, Mann GJ, Hughes TM, Thompson JF, Scolyer RA, Kefford RF. Prognostic and clinicopathologic associations of oncogenic BRAF in metastatic melanoma. J Clin Oncol. 2011;29:1239-46.

8. Jakob JA, Bassett RL Jr, Ng CS, Curry JL, Joseph RW, Alvarado GC, Rohlfs ML, Richard J, Gershenwald JE, Kim KB, Lazar AJ, Hwu P, Davies MA. NRAS mutation status is an independent prognostic factor in metastatic melanoma. Cancer. 2012;118:4014-23. 
9. Chen G, McQuade JL, Panka DJ, Hudgens CW, Amin-Mansour A, Mu XJ, Bahl S, Jane-Valbuena J, Wani KM, Reuben A, Creasy CA, Jiang H, Cooper ZA, Roszik J, Bassett RL Jr, Joon AY, Simpson LM, Mouton RD, Glitza IC, Patel SP, Hwu WJ, Amaria RN, Diab A, Hwu P, Lazar AJ, Wargo JA, Garraway LA, Tetzlaff MT, Sullivan RJ, Kim KB, Davies MA. Clinical, molecular, and immune analysis of dabrafenib-trametinib combination treatment for BRAF inhibitor-refractory metastatic melanoma: A phase 2 clinical trial. JAMA Oncol. 2016;2:1056-64.

10. Cancer Genome Atlas N. Genomic Classification of Cutaneous Melanoma. Cell. 2015;161:1681-96.

11. Falchook GS, Long GV, Kurzrock R, Kim KB, Arkenau TH, Brown MP, Hamid O, Infante JR, Millward M, Pavlick AC, O’Day SJ, Blackman SC, Curtis CM, Lebowitz P, Ma B, Ouellet D, Kefford RF. Dabrafenib in patients with melanoma, untreated brain metastases, and other solid tumours: A phase 1 doseescalation trial. Lancet. 2012;379:1893-1901.

12. Long GV, Trefzer U, Davies MA, Kefford RF, Ascierto PA, Chapman PB, Puzanov I, Hauschild A, Robert C, Algazi A, Mortier L, Tawbi H, Wilhelm T, Zimmer L, Switzky J, Swann S, Martin AM, Guckert M, Goodman V, Streit M, Kirkwood JM, Schadendorf D. Dabrafenib in patients with Val600Glu or Val600Lys BRAF-mutant melanoma metastatic to the brain (BREAK-MB): A multicentre, open-label, phase 2 trial. Lancet Oncol. 2012;13:1087-95.

13. Tsao H, Chin L, Garraway LA, Fisher DE. Melanoma: From mutations to medicine. Genes Dev. 2012;26:1131-55.

14. Brose MS, Volpe P, Feldman M, Kumar M, Rishi I, Gerrero R, Einhorn E, Herlyn M, Minna J, Nicholson A, Roth JA, Albelda SM, Davies H, Cox C, Brignell G, Stephens P, Futreal PA, Wooster R, Stratton MR, Weber BL. BRAF and RAS mutations in human lung cancer and melanoma. Cancer Res. 2002;62:69977000.

15. Yaman B, Akalin T, Kandiloglu G. Clinicopathological characteristics and mutation profiling in primary cutaneous melanoma. Am J Dermatopathol. 2015;37:389-97.

16. Satzger I, Marks L, Kerick M, Klages S, Berking C, Herbst R, Volker B, Schacht V, Timmermann B, Gutzmer R. Allele frequencies of BRAFV600 mutations in primary melanomas and matched metastases and their relevance for BRAF inhibitor therapy in metastatic melanoma. Oncotarget. 2015;6:37895-905.

17. Siroy AE, Boland GM, Milton DR, Roszik J, Frankian S, Malke J, Haydu L, Prieto VG, Tetzlaff M, Ivan D, Wang WL, TorresCabala C, Curry J, Roy-Chowdhuri S, Broaddus R, Rashid A, Stewart J, Gershenwald JE, Amaria RN, Patel SP, Papadopoulos NE, Bedikian A, Hwu WJ, Hwu P, Diab A, Woodman SE, Aldape KD, Luthra R, Patel KP, Shaw KR, Mills GB, Mendelsohn J, Meric-Bernstam F, Kim KB, Routbort MJ, Lazar AJ, Davies MA. Beyond BRAF(V600): Clinical mutation panel testing by next-generation sequencing in advanced melanoma. J Invest Dermatol. 2015;135:508-15.

18. Yaman B, Kandiloglu G, Akalin T. BRAF-V600 mutation heterogeneity in primary and metastatic melanoma: A study with pyrosequencing and immunohistochemistry. Am J Dermatopathol. 2016;38:113-20.
19. Akman T, Oztop I, Baskin Y, Akbarpour M, Unal OU, Oflazoglu $\mathrm{U}$, Ellidokuz H, Lebe B. The role of BRAF mutation in patients with high-risk malignant melanoma treated with high-dose adjuvant interferon therapy. Med Oncol. 2015;32:440.

20. Sener E, Yildirim P, Tan A, Gokoz O, Tezel GG. Investigation of BRAF mutation analysis with different technical platforms in metastatic melanoma. Pathol Res Pract. 2017;213:522-30.

21. Meckbach D, Bauer J, Pflugfelder A, Meier F, Busch C, Eigentler TK, Capper D, von Deimling A, Mittelbronn M, Perner S, Ikenberg K, Hantschke M, Buttner P, Garbe C, Weide B. Survival according to BRAF-V600 tumor mutations--an analysis of 437 patients with primary melanoma. PLoS One. 2014;9:e86194.

22. Hugdahl E, Kalvenes MB, Puntervoll HE, Ladstein RG, Akslen LA. BRAF-V600E expression in primary nodular melanoma is associated with aggressive tumour features and reduced survival. Br J Cancer. 2016;114:801-8.

23. Meckbach D, Keim U, Richter S, Leiter U, Eigentler TK, Bauer J, Pflugfelder A, Buttner P, Garbe C, Weide B. BRAF-V600 mutations have no prognostic impact in stage IV melanoma patients treated with monochemotherapy. PLoS One. 2014;9:e89218.

24. Inumaru JS, Gordo KI, Fraga Junior AC, Silva AM, Leal CB, Ayres FM, Wastowski IJ, Borges NF, Saddi VA. Analysis of the BRAF V600E mutation in primary cutaneous melanoma. Genet Mol Res. 2014;13:2840-8.

25. Hong JW, Lee S, Kim DC, Kim KH, Song KH. Prognostic and Clinicopathologic Associations of BRAF Mutation in Primary Acral Lentiginous Melanoma in Korean Patients: A preliminary study. Ann Dermatol. 2014;26:195-202.

26. Roh MR, Eliades P, Gupta S, Tsao H. Genetics of melanocytic nevi. Pigment Cell Melanoma Res. 2015;28:661-72.

27. Griewank KG, Murali R, Puig-Butille JA, Schilling B, Livingstone E, Potrony M, Carrera C, Schimming T, Moller I, Schwamborn M, Sucker A, Hillen U, Badenas C, Malvehy J, Zimmer L, Scherag A, Puig S, Schadendorf D. TERT promoter mutation status as an independent prognostic factor in cutaneous melanoma. J Natl Cancer Inst Monogr 2014;2014:106-14.

28. Vallarelli AF, Rachakonda PS, Andre J, Heidenreich B, Riffaud L, Bensussan A, Kumar R, Dumaz N. TERT promoter mutations in melanoma render TERT expression dependent on MAPK pathway activation. Oncotarget. 2016;7:53127-36.

29. Ferrara G, De Vanna AC. Fluorescence in situ hybridization for melanoma diagnosis: A review and a reappraisal. Am J Dermatopathol. 2016;38:253-69.

30. Yilmaz I, Gamsizkan M, Kucukodaci Z, Berber U, Demirel D, Haholu A, Narli G. BRAF, KIT, NRAS, GNAQ and GNA11 mutation analysis in cutaneous melanomas in Turkish population. Indian J Pathol Microbiol. 2015;58:279-84.

31. Cirenajwis H, Lauss M, Ekedahl H, Torngren T, Kvist A, Saal LH, Olsson H, Staaf J, Carneiro A, Ingvar C, Harbst K, Hayward NK, Jonsson G. NF1-mutated melanoma tumors harbor distinct clinical and biological characteristics. Mol Oncol. 2017;11:43851. 